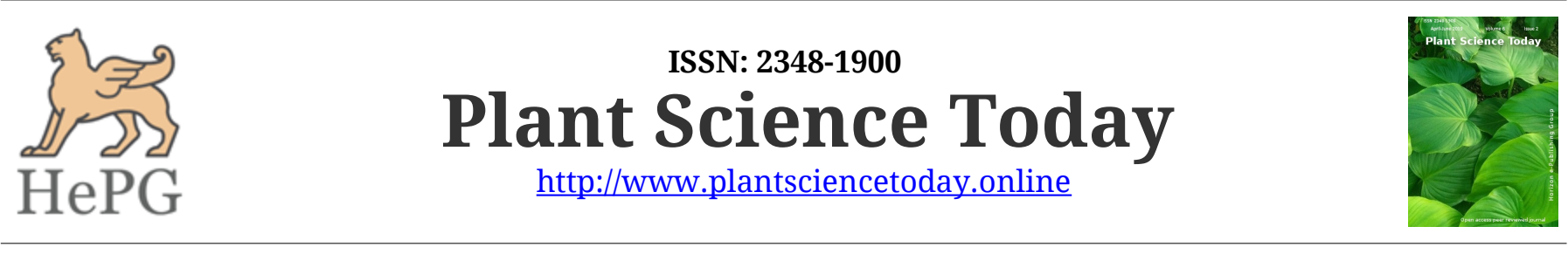

OPEN ACCESS

Research Article

\title{
Traditional knowledge and ways of consumption of wild edible plants by rural communities of Shimla District, Himachal Pradesh (India)
}

\author{
Rinku Jhamta*, Richa Puri, M L Sharma, Harsimran Kaur \& Sana Khan \\ Department of Botany, Panjab University, Chandigarh 160014, India
}

\section{Article history}

Received: 25 February 2019

Accepted: 18 April 2019

Published: 09 May 2019

\begin{abstract}
Wild edible plants are used as a source of food by local people where they still rely on natural resources to meet their daily needs. The study was conducted in the rural communities of the Shimla district to document wild edible plants and their edible uses known to local people. The study documented 103 wild edible plant species belonging to 75 genera and 46 families. Rosaceae is the most dominant family with 18 species occupying $17 \%$ of the total use reports. Of the reported plants $43 \%$ were used as fruits, $42 \%$ as vegetables and remaining have used as juice, gums, spices and condiments. As many as 74 ways of consumption methods shows a Fidelity level (FL) of more than $80 \%$. The use category of vegetables shows highest degree of consensus factor followed by fruit category. Horticultural land expansion is the major threat to the natural habitat of wild edible plants followed by overgrazing. Field visits to various villages in 16 regions of the study area were carried out in different phases from May 2015- September 2018. A total of 102 informants were involved in field investigation and a semi-structured questionnaires and participatory rural appraisal method were used to analyze and study the traditional wild edible plants.
\end{abstract}

Keywords: Natural resources; Fidelity level; Consensus factor; Natural habitat; Informants

Citation: Jhamta R, Puri R, Sharma ML, Kaur H, Khan S. Traditional knowledge and ways of consumption of wild edible plants by rural communities of Shimla District, Himachal Pradesh (India). Plant Science Today 2019;6(2):201-207. https://doi.org/10.14719/pst.2019.6.2.507

Copyright: (C) Jhamta et al (2019). This is an open-access article distributed under the terms of the Creative Commons Attribution License, which permits unrestricted use, distribution, and reproduction in any medium, provided the original author and source are credited (https://creativecommons.org/licenses/by/4.0/).

Indexing: Plant Science Today is covered by Scopus, CAS, AGRIS, CABI, Google Scholar, etc. Full list at http://www.plantsciencetoday.online
*Correspondence
Rinku Jhamta
$\square_{\text {rinkujhamta90@gmail.com }}$
Horizon e-Publishing Group still meets their daily nutritional requirement by consuming various wild plants. In rural villages wild edible plants act as good substitutes at times of food shortage (2). In developing countries wild edible plants also offer an alternative source of income (3-5).

Many of the wild edible plants and their way of eating are restricted to certain communities 
and are unknown to others. The knowledge about the wild edible plants has came from the age old experiences of ancient people and is transmitted orally from one generation to another. But the knowledge about these wild edible plants is declining due to various factors such as population migration to urban areas, declining of natural resources and changing cultural tradition (6-8). Due to rapid decline of traditional knowledge related to wild edible plants and increased reliance on limited crops, evaluation and survey of these plants species are important.

The first floral investigation of study area finds back in early nineteenth century in the book Flora Simlensis (9). Chowdhery and Wadhawa in 1984 published three volumes of 'Flora of Himachal Pradesh' (10). Nair in 1977 documented 846 plants in his 'Flora of Bushahr Himalaya' (11). The latest floral diversity around Shimla water catchments sanctuary reported 478 vascular plants (12).

Ethnobotany is a multidisciplinary science which deals with the interaction of humans with plants and ecosystem. It gives the broad idea that how the people of a particular region and culture make use of indigenous plants. Despite the considerable exploration and development in floristic study of the area, there is no ethnobotanical study related to the traditional knowledge of wild edible plants of Shimla District. The aim of this study was to document the knowledge and uses of wild edible plants in Shimla district. The present study is the first documentation of orally transmitted traditional knowledge of wild edible plants from rural villages of Shimla district.

\section{Materials and Methods}

\section{Study Area}

The Shimla district lies between longitude 77.00" and 78.19" east and latitude 30.45" and 31.44" north. The altitude of the study area ranges from $300 \mathrm{~m}$ to $6000 \mathrm{~m}$ with annual average temperature of $17{ }^{\circ} \mathrm{C}$. The annual precipitation is $1028 \mathrm{~mm}$ majority of which is received during rainy season (13). The geographical area of the district is 5,131 $\mathrm{km}^{2}$ which constitutes the $9.22 \%$ of the area of Himachal Pradesh. The study is divided into 12 Tehsils, 6 sub-Tehsils with 2,914 villages. According to 2011 census Shimla district has population of 813,384 with population density of 159 people per $\mathrm{km}^{2}$ (14). Hindi and Pahari are the most spoken language. Tourism and agriculture are the major source of income of the native people and the study area is famous for its apple production. Satluj, Pabbar and Giri are the three main river systems flowing through the district. The district vegetation falls within the four geographic zones- alpine, subalpine, temperate and intermediate zones (13). Due to the great variation in the altitude and topography the study area has rich and diverse vegetation.

Table 1. Demographic Characteristics and Educational background

\begin{tabular}{ll}
\hline Total informants & 102 \\
\hline Male & $41(40.2 \%)$ \\
\hline Female & $61(59.8 \%)$ \\
\hline Age group (11-30) & $14(14.28 \%)$ \\
\hline Age group (31-50) & $29(29.58 \%)$ \\
\hline Age group (51-70) & $47(47.49 \%)$ \\
\hline Age group (71-90) & $12(12.24 \%)$ \\
\hline Never attended school & $44(43.1 \%)$ \\
\hline Attended school for less than 5 years & $29(28.4 \%)$ \\
\hline Finished middle school & $18(17.6 \%)$ \\
\hline Finished high school & $11(10.8 \%)$ \\
\hline
\end{tabular}

\section{Field survey and data collection}

Field visits to various villages of the Shimla districts were carried out in different phases from May 2015- September 2018 to collect the information about wild edible plants being used by the locals. Prior consent was obtained from informants by explaining them the aim of the study. A total of 102 (61 females and 41 males) informants were interviewed who possess the knowledge about the wild edible plants (Table 1). A semi structured interviews were conducted with individuals in the local and Hindi language and ethno botanical data were collected and further verified with elderly people and healers. Ethno botanical information was gathered, confirmed and validated by Rapid Rural Appraisal (RRA) (15). In addition to the individual interviews, various random group discussions were held in order to understand and validate the knowledge of the local people. Informants included were children, students, elders, shepherds, old ladies, local hakims etc. with age ranging from 13 to 84 years (median $=53)$.

The topics of main interest covered during discussions and interviews were the vernacular name(s) of edible plants growing in the wild, edible parts used, seasonal availability, frequency of use, ways of consumption and preparation of the edible parts and their personal taste experience for the plant. In addition, traditional uses, management practices and other threats to their natural habitat if any were also recorded.

The plants were collected and photographed during field trips. The same plants were again photographed and collected during their flowering or fruiting seasons. The identification was later confirmed by matching the specimens and other authentically identified specimens deposited in Herbarium of Panjab 


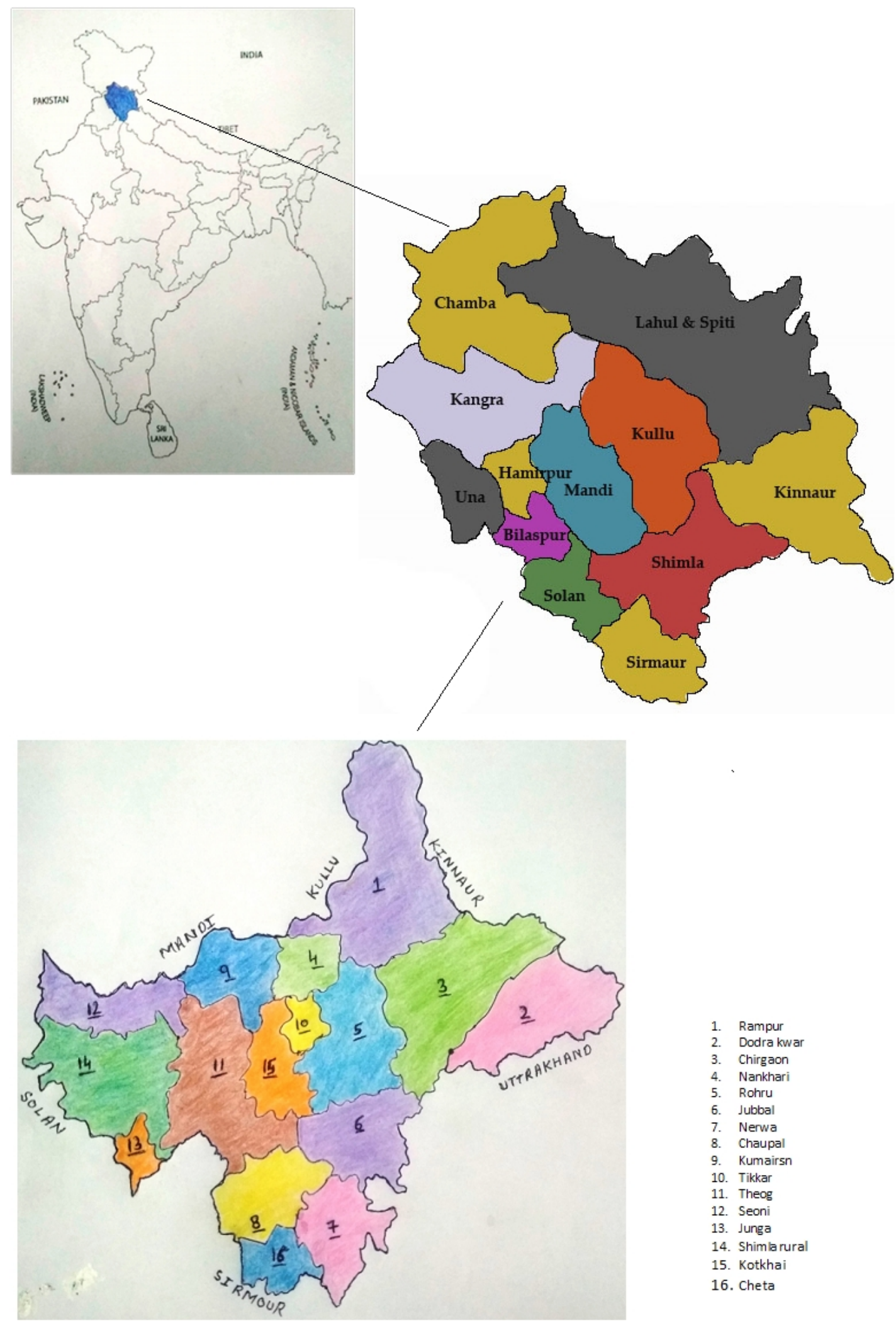

Fig. 1. Location map of the study area

University Chandigarh (PAN), Herbarium of Botanical Survey of India (BSD) and Herbarium of Himachal Forest Research Institute, Shimla.

\section{Data Analysis}

Since most of the data collected in the study were descriptive in nature and therefore they were explained directly. The data obtained from questionnaires and interviews were analyzed by the fidelity level (FL) method and Information
Consensus Factor (ICF). The wild edible plants were classified into eight categories based on the recipes and usage method, viz., Vegetables cooked (Vc), Vegetables raw (Vr), Fruits cooked (Fc), Fruits raw (Fr), Beverages (Bv), Chutneys (Ch), Spices \& Condiments (S\&C) and Others (Ot).

The fidelity level (FL) method is used to determine the importance of plant species mentioned by participants for certain preparatory 


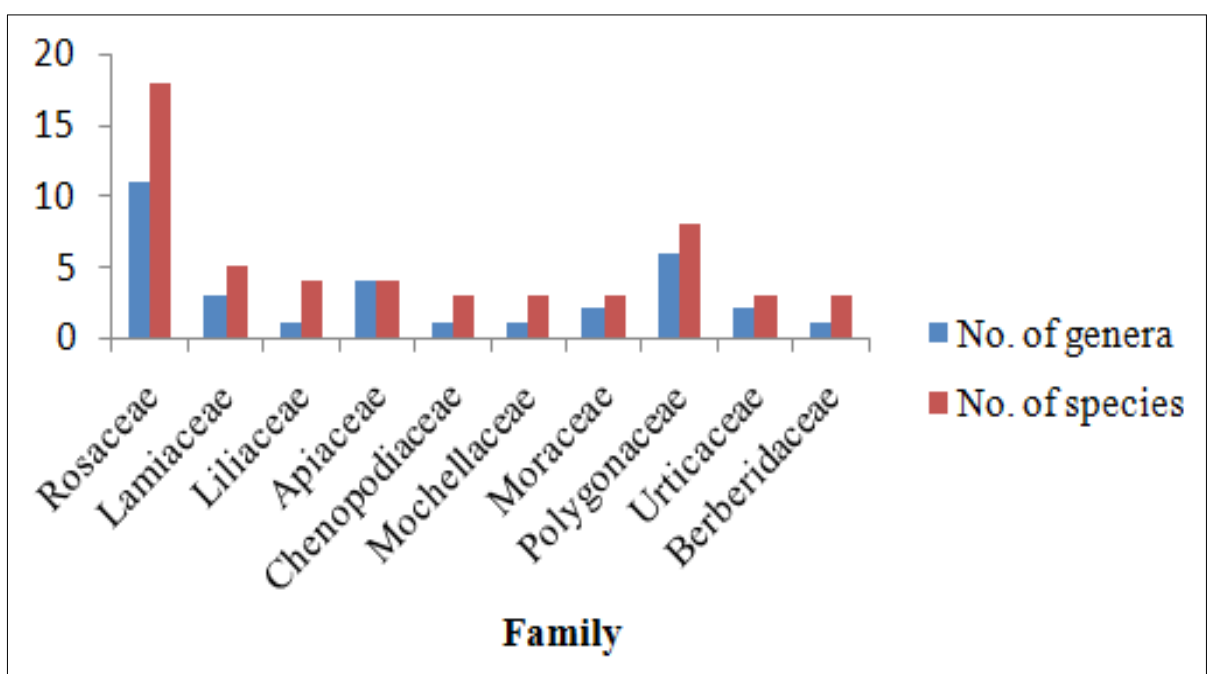

Fig. 2. Most represented wild edible families and number of genera/species in the study area

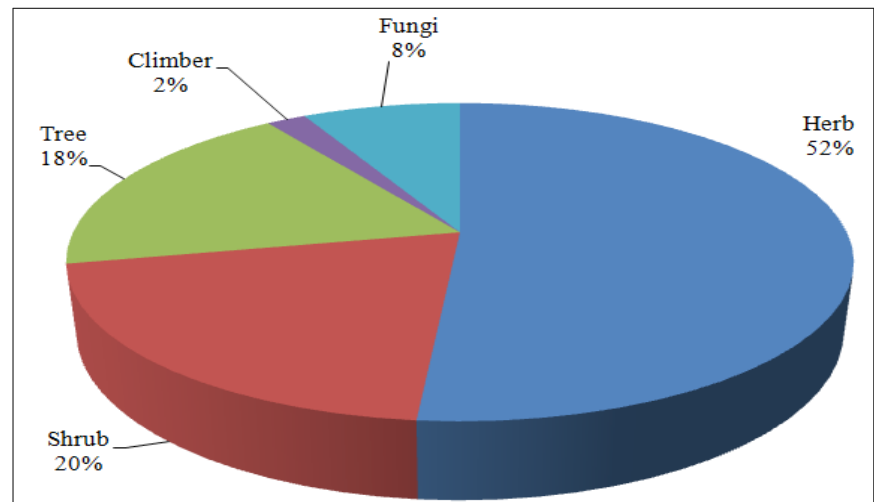

Fig. 3. Wild edible life form in the study area

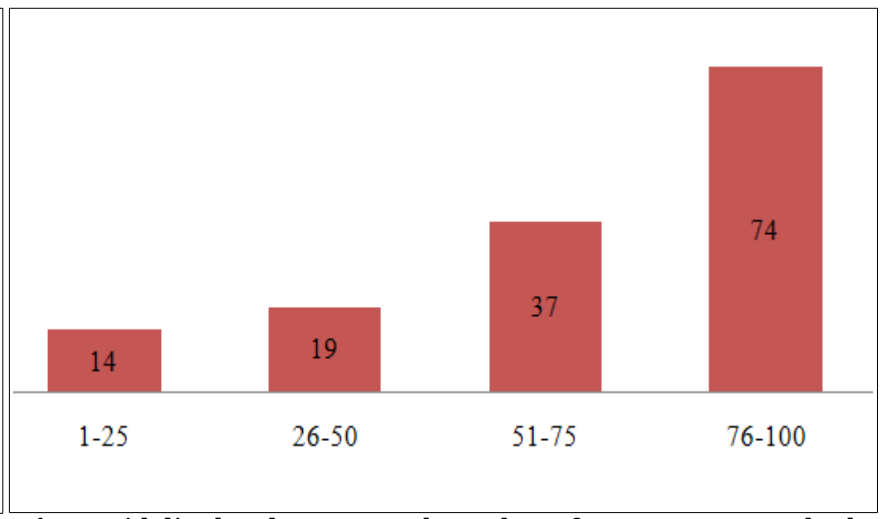

Fig. 4. Fidelity level ranges and number of preparatory methods from the study area methods (16). The fidelity level (FL) is calculated using the formula: $\mathrm{FL}(\%)=\mathrm{N}_{\mathrm{p}} \times 100 / \mathrm{N}$, where $\mathrm{N}_{\mathrm{p}}$ is the number of informants that mentioned the particular plant used with certain preparatory methods, $\mathrm{N}$ is those total number of informants that uses plants for any given preparatory method. Information Consensus Factor (ICF) was calculated as: ICF $\left.=\left(n_{u r}-n_{t}\right) / n_{u r}-1\right)$, where $n_{u r}$ refers the number of use reports for a particular use category and $n_{t}$ is the number of plant species used for particular use category by all informants (17).

\section{Results and Discussion}

\section{Taxonomic Diversity}

The great diversity of wild edible plant species offers a various diet to local communities. The traditional knowledge about wild edible plants and their ways of eating are mainly confined to elderly women. The reason for the above trend is that they are more involved in household and livestock rearing activities. In the present investigation a total 103 plants were reported to be edible in rural communities of Shimla district (Table 2 - See Supplementary Table). Out of the total 103 species 6 belongs to fungi, 2 species of ferns, a single species of gymnosperm and rest 94 are angiosperms. These wild edible plant species are classified among 46 families and 75 genera. With respect to the diversity of the wild edible plant species gathered Rosaceae was the most important botanical family with 18 species representing the $17 \%$ of the total use reports followed by Polygonaceae with 8 species representing the $7 \%$ of the total use reports followed by Lamiaceae, Liliaceae and Apiaceae (Fig. 2). Rosaceae being the most dominant family correlated with the studies done in wild edible plants (18-21). However, Leguminosae is the most important plant family in Udampur district of Jammu \& Kashmir state of India owing to the higher use of legumes in their eating habits of wild plants (22). The families such as Rosaceae and Polygonaceae showing largest percentages are common in the study area. Therefore locals prefer those plants which are easily available to them.

\section{Fidelity level (FL)}

The method is used to identify the most preferred plant species and its preparatory methods. A total of 144 ways of preparatory methods are documented in the study area. Fidelity value ranges from 1.8 to $100 \%$. The present study identifies 74 preparatory methods whose fidelity 
Table 3. Information Consensus Factor (IFC) for eight use categories

\begin{tabular}{cccc}
\hline Use-Category & Number of species & Use-report (UR) & ICF \\
\hline Vegetables & 44 & 334 & 0.87 \\
\hline Vegetables cooked (Vc) & 59 & 322 & 0.88 \\
\hline Vegetables raw (Vr) & 5 & 12 & 0.63 \\
\hline Fruits cooked (Fc) & 4 & 13 & 0.75 \\
\hline Fruits raw (Fr) & 41 & 281 & 0.85 \\
\hline Beverages (Bv) & 5 & 11 & 0.60 \\
\hline Chutneys (Ch) & 9 & 28 & 0.70 \\
\hline Spices \& condiments (S\&C) & 18 & 56 & 0.69 \\
\hline Others (Ot): Pickles, Pakodas, Tea, & 8 & 19 & 0.61
\end{tabular}

Table 4. Results of pair wise ranking of factors considered as threats to wild edible plants of study area

\begin{tabular}{cccccccc}
\hline Factors & \multicolumn{9}{c}{ Respondents } & Total & Rank \\
\hline & RA $^{*}$ & $\mathbf{C H}^{*}$ & JU* & KO $^{*}$ & SE* $^{*}$ & & 26 \\
\hline Overgrazing & 7 & 6 & 4 & 4 & 5 & 4 & 3 \\
\hline Timber harvesting & 6 & 4 & 6 & 4 & 4 & 16 & 3 \\
\hline Fuel wood collection & 2 & 3 & 4 & 3 & 4 & 5 & 1 \\
\hline Horticultural land expansion & 6 & 6 & 7 & 6 & 2 & 14 & 5
\end{tabular}

RA* Rampur, CH* Chaupal, JU* Jubbal, KO* Kothkhai, SE* Seoni. The scores from 8 key informants were pooled together from five sub sites of study area

value ranges from 76-100\% (Fig. 4). A high Fidelity level (FL) indicates that the preparatory method is most preferred (23). The plants with lower FL values were Bergenia ciliata (Haworth) Sternberg, Bergenia strachheyi (Hook. f. \& Thom.) Engl., Bistorta vivipara (Linn.) S.F. Gray, Galium aparine Linn., Murraya koenigii (L.) Sprengel etc. The Fidelity level (FL) of $100 \%$ were also observed in three wild fruits species, viz., Berberis lycium Royle., Prunus armeniaca Linn. and Rubus ellipticus Smith. which correlated with the studies done in Churah subdivision of Chamba district of Himachal Pradesh (24).

\section{Information Consensus Factor (ICF)}

Out of the eight use categories of ICF, vegetable cooked (Vc) shows the highest degree of consensus factor (0.88) and Beverages (Bv) shows the lowest degree of consensus (0.60) (Table 3). Fruits eaten raw (Fr) also shows high consensus factor which is similar with the other studies conducted by Kumar et al., Bhatia et al., and Singh et al. (25-27). These results interprets that people have high level of traditional knowledge about the eating ways of wild edible plants which is significantly shared among the inhabitants.

\section{Threats to wild edible plants and Conservation issues}

The field analysis revealed that the many human activities are putting wild edible species under constant threat in their natural habitat. Activities like horticultural land expansion, timber harvesting, road construction, overgrazing of forest land and fuel wood collection are the most common threats. Pair wise ranking of these threatening activities shows that horticultural land expansion is the major threat to the wild edible plants of Shimla district followed by overgrazing, timber harvesting, fuel wood collection and road constructions (Table 4). These finding are different from the study conducted on wild edible plants of Nepal where habitat destruction is the major threat (28). Plants with fair market prize are also under threat because of excessive collection and unhealthy competition among the collectors (29).

\section{Conclusion}

The current study investigates the plants of Shimla district focusing on edible parts and their role in day to day household food needs and also at a time of food shortage. These include edible plants gathered as food by elders and ripened fruits consumed by children. The results of the study indicate that the traditional knowledge about the wild edible plants is still prevalent in the study area. By studying the remote villages it is clear that wild edible plants are integral part of their day to day diatery habits and some of them are source their income. As many as 32 ways of preparatory methods shows a fidelity level (FL) of $100 \%$, which can be used as an alternative food resources through further study. Local inhabitants feel privileged about the knowledge they possess about these wild edible plants. Field investigation revealed that the most of these plants are consumed by relatively poor households. Rapid 
globalization and easy availability of crop foods results into a significant decrease in the usage of these wild edible plants. This may threaten the loss of traditional knowledge about these valuable food plants. So the presented data would greatly assist the locals in promoting their involvement in conservation and management of natural resources.

\section{Acknowledgements}

The authors are extremely grateful to the informants and villagers of the Shimla district for their assistance and cooperation during data collection. Rinku Jhamta would like to acknowledge the UGC for providing financial assistance. Authors are also thankful to herbarium staff of Department of Botany, Panjab University, BSI Dehradun and HFRI Shimla for specimen identification.

\section{Authors' contributions}

RJ conducted field visit. HK and SK later on joined field visit, data collection and drafting of manuscript. RP and MLS involved in design of research analysis and approval of final manuscript.

\section{Competing interest}

The authors declare that they have no competing interests.

\section{References}

1. Konsam S, Thongam B, Handique AK. Assessment of wild leafy vegetables traditionally consumed by the ethnic communities of Manipur, northeast India. Journal of ethnobiology and ethnomedicine. 2016;12(1):9. https://doi.org/10.1186/s13002-016-0080-4

2. Harris FM, Mohammed S. Relying on nature: wild foods in northern Nigeria. AMBIO: A Journal of the Human Environment. 2003;32(1):24-30. https://doi.org/ 10.1579/0044-7447-32.1.24

3. Gemedo-Dalle $\mathrm{T}$, Maass $\mathrm{BL}$, Isselstein J. Plant biodiversity and ethnobotany of Borana pastoralists in southern Oromia, Ethiopia. Economic Botany. 2005;59(1):43-65. https://doi.org/10.1663/00130001(2005)059[0043:PBAEOB]2.0.CO;2

4. Shrestha PM, Dhillion SS. Diversity and traditional knowledge concerning wild food species in a locally managed forest in Nepal. Agroforestry Systems. 2006;66(1):55-63. https://doi.org/10.1007/s10457-005$\underline{6642-4}$

5. Teklehaymanot T, Giday M. Ethnobotanical study of wild edible plants of Kara and Kwego semi-pastoralist people in Lower Omo River Valley, Debub Omo Zone, SNNPR Ethiopia. Journal of ethnobiology and ethnomedicine. https://doi.org/10.1186/1746-4269-6-23

6. Reyes-García V, Menendez-Baceta G, Aceituno-Mata L, Acosta-Naranjo R, Calvet-Mir L, Domínguez P, Garnatje
T, Gómez-Baggethun E, Molina-Bustamante M, Molina M, Rodríguez-Franco R. From famine foods to delicatessen: Interpreting trends in the use of wild edible plants through cultural ecosystem services. Ecological Economics. 2015;120:303-11. https://doi.org/ 10.1016/j.ecolecon.2015.11.003

7. Rao PK, Hasan SS, Bhellium BL, Manhas RK. Ethnomedicinal Plants of Kathua District, J\&K, India. Journal of ethnopharmacology. 2015;171:12-27. https:// doi.org/10.1016/j.jep.2015.05.028

8. Łuczaj Ł, Končić MZ, Miličević T, Dolina K, Pandža M. Wild vegetable mixes sold in the markets of Dalmatia (southern Croatia). Journal of ethnobiology and ethnomedicine. https://doi.org/10.1186/1746-4269-9-2 2013;9(1):2.

9. Collett H. Flora Simlensis: A Handbook of the flowering plants of Simla and the neighbourhood. Thacker, Spink \& Co.;1902.

10. Chowdhery HJ, Wadhwa BM. Flora of Himachal Pradesh, Vol. 1. BSI, Kolkata;1984.

11. Nair NC. Flora of Bushahr Himalayas. International Biosciences Publishers, Madras;1977.

12. Rana D, Kapoor KS. Assessment of Floristic Diversity of Shimla water catchment Sanctuary, Himachal Pradesh India. The Indian Forester. 2015;141(12):1244-1247.

13. Jagmohan B. The Wonderland of Himachal Pradesh. HG publication, New Delhi;1998.

14. Directorate of Census Operations. District census Handbook Shimla, Himachal Pradesh;2011.

15. Martin GJ. Ethnobotany: A methods manual. London: Chapman and Hall;1995.

16. Alexiades MN, Sheldon JW. Selected guidelines for ethnobotanical research: a field manual. New York Botanical Garden, New York;1996.

17. Heinrich M, Edwards S, Moerman DE, Leonti M. Ethnopharmacological field studies: a critical assessment of their conceptual basis and methods. Journal of Ethnopharmacology. 2009;124(1):1-17. https://doi.org/10.1016/j.jep.2009.03.043

18. Geng Y, Zhang Y, Ranjitkar S, Huai H, Wang Y. Traditional knowledge and its transmission of wild edibles used by the Naxi in Baidi Village, northwest Yunnan province. Journal of ethnobiology and ethnomedicine. 2016;12(1):10 https://doi.org/10.1186/s13002-016-0082-2

19. Thakur D, Sharma A, Uniyal SK. Why they eat, what they eat: patterns of wild edible plants consumption in a tribal area of Western Himalaya. Journal of ethnobiology and ethnomedicine. 2017;13(1):70. https://doi.org/10.1186/s13002-017-0198-Z

20. Singh B, Sultan P, Hassan QP, Gairola S, Bedi YS. Ethnobotany, Traditional Knowledge, and Diversity of Wild Edible Plants and Fungi: A Case Study in the Bandipora District of Kashmir Himalaya, India. Journal of Herbs, Spices \& Medicinal Plants 2016;22(3):247-278. https://doi.org/10.1080/10496475.2016.1193833

21. Menendez-Baceta G, Aceituno-Mata L, Reyes-García V, Tardío J, Salpeteur M, Pardo-de-Santayana M. The importance of cultural factors in the distribution of medicinal plant knowledge: a case study in four Basque regions. Journal of Ethnopharmacology. 2015;161:116-27.

https://doi.org/10.1016/j.jep.2014.12.007 
22. Bhatia H, Sharma YP, Manhas RK, Kumar K. Traditionally used wild edible plants of district Udhampur, J\&K India. Journal of ethnobiology and ethnomedicine. 2018;14(1):73 https://doi.org/10.1186\%2Fs13002-018-0272-1

23. Singh A, Nautiyal MC, Kunwar RP, Bussmann RW. Ethnomedicinal plants used by local inhabitants of Jakholi block, Rudraprayag district, Western Himalaya, India. Journal of Ethnobiology and Ethnomedicine. 2017;13(1):49. https://doi.org/10.1186/s13002-017-0178-3

24. Rana D, Bhatt A, Lal B. Ethnobotanical knowledge among the semi-pastoral Gujjar tribe in the high altitude (Adhwari's) of Churah subdivision, district Chamba, Western Himalaya. Journal of Ethnobiology and Ethnomedicine. 2019;15(1):10 https://doi.org/10.1186/s13002-019-0286-3

25. Kumar K, Sharma YP, Manhas RK, Bhatia $H$. Ethnomedicinal plants of Shankaracharya Hill, Srinagar, J\&K, India. Journal of ethnopharmacology. 2015;170:255-74.

https://doi.org/10.1016/j.jep.2015.05.021
26. Bhatia H, Sharma YP, Manhas R.K, Kumar K. Traditional phytoremedies for the treatment of menstrual disorders in district Udhampur, J\&K, India. Journal of ethnopharmacology. 2015;160:202-10. https://doi.org/10.1016/j.jep.2014.11.041

27. Singh B, Sultan P, Hassan QP, Gairola S, Bedi YS. Ethnobotany, Traditional Knowledge, and Diversity of Wild Edible Plants and Fungi: A Case Study in the Bandipora District of Kashmir Himalaya, India. Journal of Herbs, Spices \& Medicinal Plants. 2016;22(3):247-78. https://doi.org/10.1080/10496475.2016.1193833

28. Uprety Y, Poudel RC, Shrestha KK, Rajbhandary S, Tiwari NN, Shrestha UB, Asselin H. Diversity of use and local knowledge of wild edible plant resources in Nepal. Journal of Ethnobiology and Ethnomedicine. 2012;8(1):16. https://doi.org/10.1186/1746-4269-8-16

29. Sundriyal M, Sundriyal RC. Wild edible plants of the Sikkim Himalaya: Marketing, value addition and implications for management. Economic Botany. 2004;58(2):300-15 